\title{
ИСКУССТВО
}

УДК 398.221(=22):[75:7.071.1Марци(571.14-25)““2015/...”]

DOI: $10.32340 / 2414-9101-2021-4-45-52$

А. А. Сухарева

Алтайский государственный институт культуры (Барнаул, Россия) aarturovna1999@mail.ru

Научный руководитель - И. В. Куприянова, доктор исторических наук, доцент Алтайский государственный институт культуры (Барнаул, Россия)

irinak-63@mail.ru

\section{ОБРАЗЫ СКИФСКОЙ МИФОЛОГИИ В ТВОРЧЕСТВЕ ХУДОЖНИКА НИКОЛАЯ МАРЦИ}

Аннотация. В статье анализируются проблемы сохранения культурно-исторической памяти в условиях разнообразия регионального наследия Сибири; обозначается важность укрепления межнациональных связей с помощью искусства, в данном случае живописи, как фиксатора культурно-исторической памяти. В качестве примера рассматривается творчество новосибирского художника Николая Марци (род. 1973 г.) как посредника между современностью и далеко от нас отстоящим в историческом прошлом миром скифов. Его картины выступают как феномен сохранения культурно-исторической памяти и воссоздают образы скифского времени, а также отражают духовную жизнь народов Горного Алтая.

Ключевые слова: культурно-историческая память, искусство, археоарт, скифы, скифо-сибирский мир, картины, Николай Маричи.

Сохранение культурно-исторической памяти является одной из актуальных и важных задач культурной политики государства: «Язык, культура, история, духовные ценности и национальные традиции - это основа основ, и внимание к ним государства, общества должно быть и будет постоянным. Только так можно уверенно развиваться, сохранять свою самобытность, сберегать себя как народ» [1].

Россия является многонациональной страной - на ее территории проживают более 180 национальностей. В этом заключается её сила и уникальность, но одновременно создаются некоторые трудности, одна из которых - необходимость, на фоне общей глобализации, сохранять культурно-историческую память каждого из этих народов. Важно отметить, что для такой большой страны необходимо постоянно укреплять и поддерживать межнациональные отношения. В укрепление мира и дружбу народов может вносить свой весомый вклад искусство, которое в ненавязчивой форме знакомит с особенностями, историей и культурой отдельных этносов, пробуждает интерес и уважение к иным традициям. 
История, духовные ценности, национальные традиции составляют ядро культурноисторической памяти народа. Существуют разные способы её сохранения: музейные археологические и этнографические коллекции, письменные источники, памятники архитектуры, а также памятники природы. Отдельной группой выделяют памятники культурного наследия, в число которых входят произведения искусства. Таким образом, одним из инструментов, фиксирующих тот или иной культурный пласт, можно назвать искусство.

Скульптура, живопись и архитектура являются прекрасным фиксатором культурной памяти, материальным воплощением нематериального наследия. В качестве глобального примера стоит привести Древнюю Грецию, искусство и мифология которой стали частью всемирного наследия: в частности, имена древнегреческих богов и героев стали именами нарицательными (Венера, Аполлон, Зевс, Прометей и т. д.).

У народов современной России также есть множество интересных мифов, унаследованных от далеких предков, но они порой остаются известными только специалистам. Очень важно возродить знания о них, поскольку этот материал наиболее наглядно демонстрирует особенности мировоззрения той или иной этнической группы.

Обычно исследователи отдают предпочтение отечественной истории, как части прошлого своего народа, а национальные музеи хранят археологические, этнографические коллекции и прочие материальные предметы, преимущественно своей территории. Но особое значение для развития межнациональных отношений имеет интерес не только к себе, а к другим народам, в том числе уже ныне не существующим. В этой связи нам бы хотелось обратить внимание на археоарт - направление в современном изобразительном искусстве Сибири, связанное с художественно-эстетическим освоением наследия древних культур [2, с. 51].

В этом направлении выстраивается творчество художника из Новосибирска Николая Марци, выставка которого, под названием «Скифы Сибири. Пробуждение», недавно прошла в Алтайском государственном краеведческом музее. Особенность представленного материала состоит в том, что художник поставил задачей восстановить ментальные связи с одной из фундаментальных культур человечества, которой около 2,5 тыс. лет - культурой скифов, и делает это посредством художественной переработки образов древней скифской мифологии, накладывая на них образы места - Горного Алтая, входившего в сферу их обитания. Н. Марци создает уникальный эпос, наполненный духами и верованиями, входившими в комплекс реально существовавших мировоззренческих представлений, подтвержденных археологическими памятниками.

Скифы - древний кочевой народ, существовавший в период VIII - IV вв. до н. э. Ареал их обитания тянется почти через всю Евразию - от Северного Причерноморья до Южной Сибири. На территории Причерноморья они являлись соседями греческих полисов; именно поэтому они попали в сферу внимания Геродота, который в своем Скифском рассказе дал их описание. Продвижение скифов в Сибирь породило так называемый скифо-сибирский мир и уникальную, неповторимую культуру [3].

В своем интервью Николай Марци задается вопросом: «А что лично для нас, для сибиряков, значит эта культура?» [4]. Когда художник еще только формируется, у него есть некоторые стереотипы относительно того, каким ему надлежит быть: он должен стать знаменитым, популярным; его картины должны дорого продаваться, только тогда он может называть себя художником. То есть, фактически его внимание сосредоточено только на себе. Если говорить о Николае Марци, то в нем, по его словам, произошла некоторая трансформация: он не делает акцент на себе и на своем творчестве, а приносит в этот мир то, чего еще нет, а именно - новый взгляд на тему скифов, который выражается с помощью особенного художественного языка. Таким образом, он фактически выступает фиксатором культурноисторической памяти скифо-сибирского мира.

Эту мысль подтверждает известный барнаульский художник Денис Октябрь, который высказался о выставке Николая Марци «Скифы Сибири. Пробуждение» следующим образом: «Его работы наполнены энергией, и эта энергия идет через века... Мне кажется, очень 


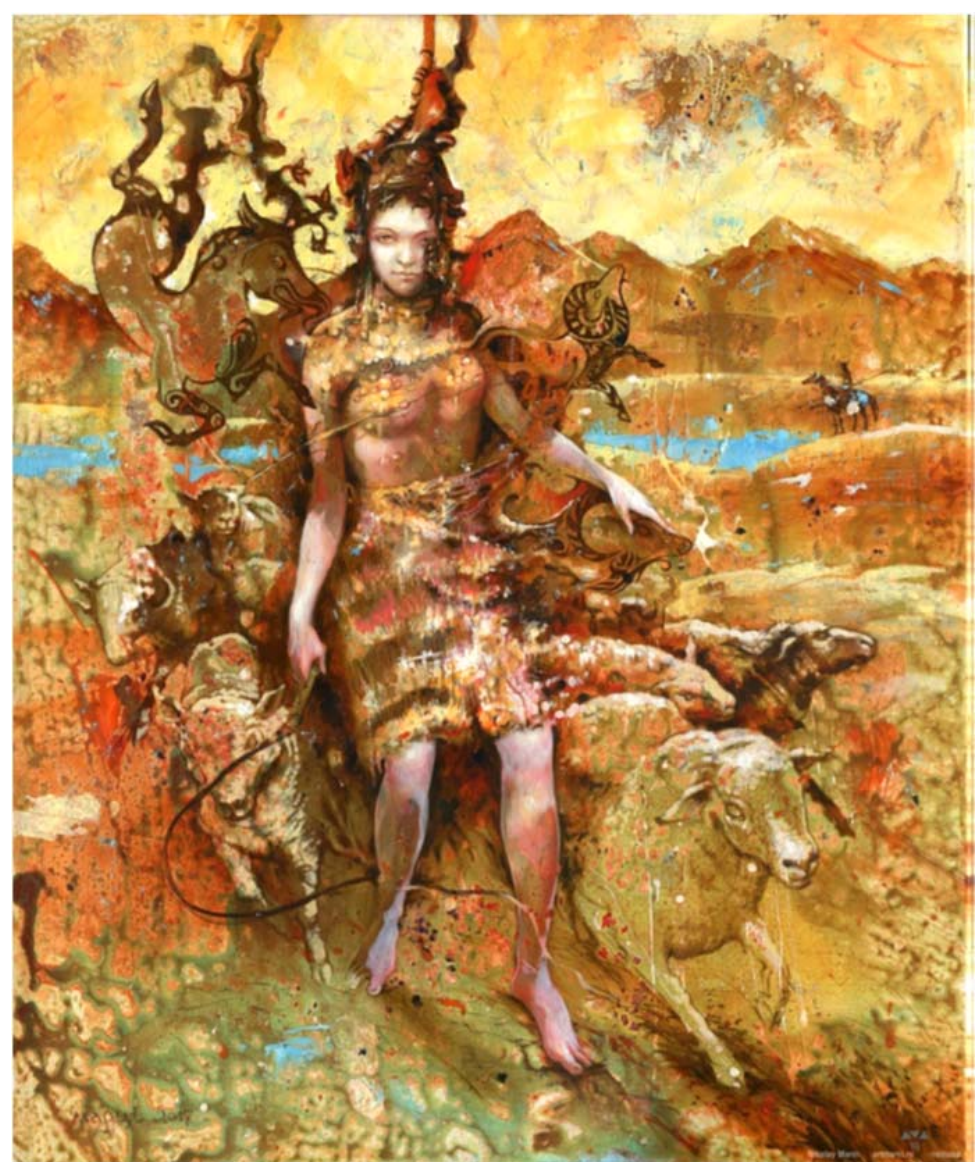

Рис. 1.

важна связь времен, и для нас, и даже для будущих поколений, потому что нас не будет, но картины останутся» [5].

Для формирования представления о творчестве художника особого внимания заслуживает его работа «Пастушка с Укока» (рис. 1), прошедшая несколько стадий и перерисовок. Автор переделывал лицо: по его словам, оно «было немного агрессивное, возможно оно было точное в плане анатомии, внутри оно не отзывалось, поэтому через год я начал все перерисовывать». Мысль, на которую нам бы хотелось обратить внимание: современный человек не хочет изображать человека, жившего около 2500 тыс. лет назад, с агрессивным выражением лица. То есть, через века и поколения художник стремится пробиться к человеческой сути людей этой отдаленной во времени, уникальной и самобытной культуры, что можно рассматривать как замечательный пример межэтнической дружбы, или даже любви.

Николаем Марци создан целый цикл картин, посвященных скифской тематике и духовной культуре Горного Алтая. Наша задача - проанализировать и выявить черты скифской культуры в творчестве современного сибирского художника, поскольку это феномен, который требует научного и искусствоведческого осмысления.

Картина «Медведь шаман» (рис. 2) иллюстрирует ритуальное действо, где три лица символизируют сочетание мужчины, женщины и мистического Духа природы. Существует предание, что шаман, входя в особое состояние, превращается в зверя, а именно в медведя. Шаманизм - одна из самых древних религий Горного Алтая. Однако в мире есть два центра шаманизма, первый из которых - Алтай, где он сложился естественным, самобытным путём.

Важно отметить, что позже он распространился не только на всю Сибирь, Восточную Азию, а также на Северную Америку. Дело в том, что в 15000-20000 лет тому назад Берингов пролив предположительно был замерзшим. Ученые называют это место Берингией; именно благодаря ей носители шаманского культа перешли по толстой корке льда на землю далекой Америки. Общие черты в культуре шаманизма в Горном Алтае и Америки помогают более ярко представить эту особую религию. Одной из таких черт является вера в возможность превращения человека в медведя (зверя); именно это состояние нам пытается передать художник.

В центре композиции мы видим сильного, крепкого бурого медведя, который держит в руках бубен - главный, неотъемлемый символ шаманизма. По бокам находятся два начала, мужское и женское. Необычным кажется то, что они все вместе существуют одновременно и сливаются в одном ритуальном обряде.

В этой картине важна каждая деталь, что соответствует высокому уровню искусства скифского времени. Искусство скифов могло проявляться в татуировках, при этом для каждой части тела предназначался ее особый вариант; так, например, на плечо наносился главный символ племени. 


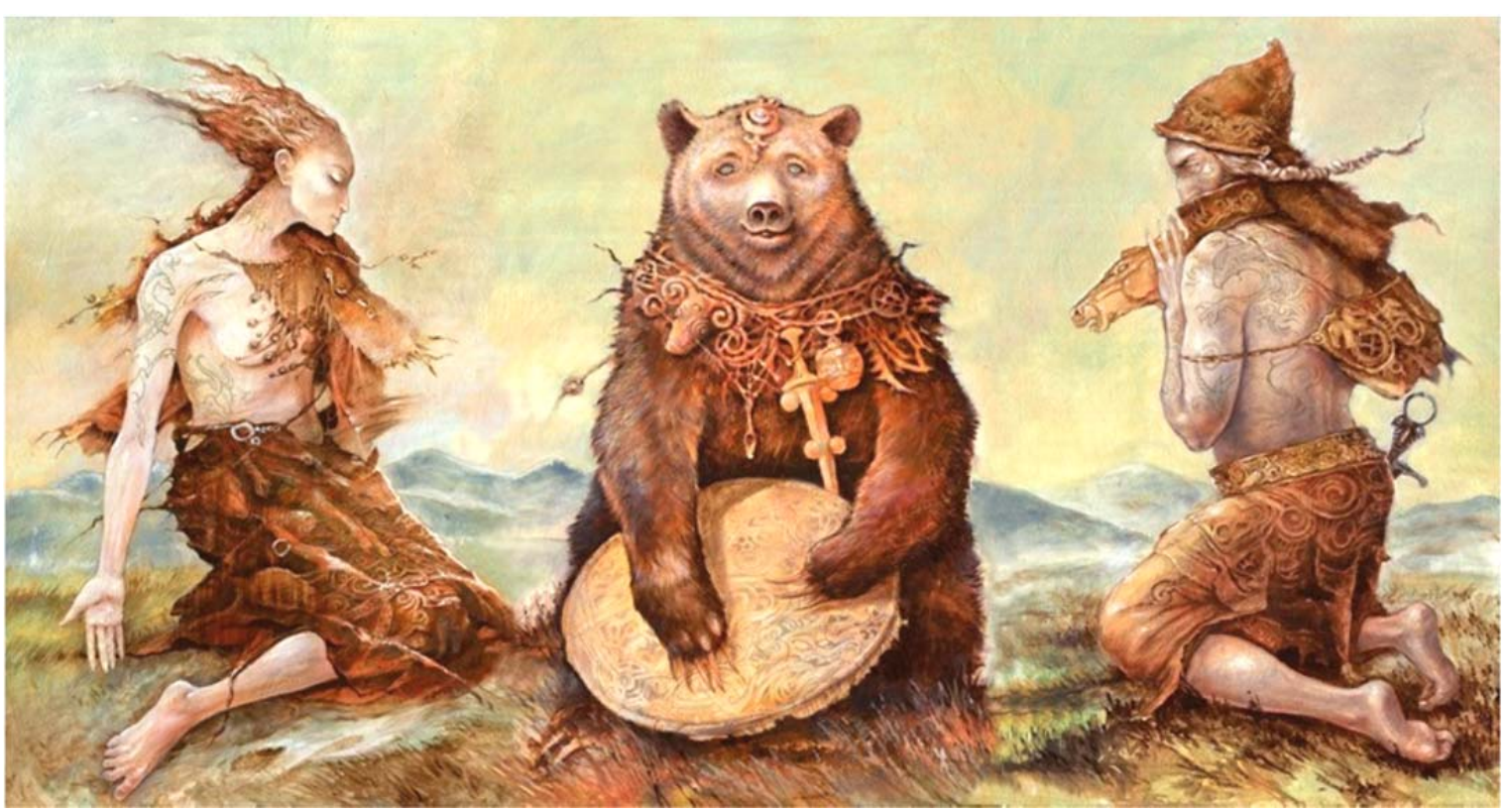

Рис. 2.

Татуировки делались не для того, чтобы их скрывать: и мужчины, и женщины обнажали части тела, на которые было нанесено изображение. Поскольку изображения носили сакральный смысл и помогали бороться со злыми духами, в процессе ритуала необходимо было снимать часть одежды, чтобы изображения были отчетливо видны.

Если обратить внимание на колорит картины, мы увидим свойственные автору теплые охристые и бурые оттенки. Благодаря этой картине мы можем представить, как происходил традиционный ритуал установления связи между реальным и потусторонним миром.

Художник в своих картинах часто изображает грифона - одну из знаменитых и в то же время загадочных фигур скифской культуры, которой посвящено много изделий прикладного искусства; это существо является мифическим и представляет собой сочетание льва и орла. Оба этих животных являются покровителями власти: лев является царём зверей, а орёл царём среди птиц. В Скифии изображение грифона часто встречается именно там, где сосредоточено много золота и богатств.

Изображение грифона на сокровищницах имеет особый смысл: его называют хранителем и покровителем власти. Эта его функция как хранителя с течением времени перешла и на охрану золота; именно поэтому их часто называют «стерегущие золото грифоны». Это мифические животное покорило сердца многих, не только художников и ювелиров, но и правителей. Считается, что в основном скифы обитали на юго-западе Европы - в Причерноморье, Украине и на Кавказе, и лишь значительно позднее они стали продвигаться на восток. Этот мифический символ очень полюбился правителям Европы, не остались к нему равнодушными и в далёкой Сибири: археологами найдено много оружия, украшений, уборов седел и уздечек с изображениями грифона. Этот образ использован на картине Н. Марци «Полет грифона», изображающей сказочный полет скифской девочки во сне (рис. 3). Картина, созданная автором в 2019 году, символизирует тесную связь человека с мифическим потусторонним миром: ведь сон во все времена имел для этой связи большое значение. Часто именно во сне человеку открывалось сакральное знание, что можно наблюдать в греческой мифологии. Во сне к герою могли приходить боги и богини и давать наставления, которые помогали уберечь душу юноши. Встреча с мифологическими животными или богинями является частым сюжетом мифологии древнего мира.

В центре картины изображена девочка, которой снится, будто она летит на сказочном грифоне, сильном и крепком, легко парящем в облаках. Крылья могут унести его в самые далекие и неведомые края. «Грифон, стерегущий золото», сам как будто состоит из золота, но это не мешает ему мягко парить в облаках. В этой работе Н. Марци отражена тесная 
связь человека с миром мифов и мифологем: она была характерна для людей скифского времени.

Картина «Всадник на рогатом коне» (рис. 4) выполнена в 2020 году. Этой работе присущи блеск и завораживающая красота. В картине гармонично сочетаются элементы «скифской триады», составляющей особенность всех культур скифо-сибирского мира, благодаря которой его можно рассматривать как единое культурно-историческое целое. Это единство было отмечено еще в конце XIX в. на основании анализа археологических материалов. Первый компонент триады - оружие, классическим эталоном которого является скифский меч - «акинак». Вторая группа скифской триады включает предметы конской сбруи, прежде всего бронзовые удила и псалии с характерными отверстиями для крепления.

Третья группа триады - самая интересная для художников: ее составляют предметы, выполненные из бронзы и дерева, в так называемом зверином стиле, характерном для всего скифского мира. Именно звериный стиль символизирует общность и единство большой территории, на которой жили скифы: от Северного Причерноморья до Южной Сибири. Если говорить о скифском искусстве в целом, то мы увидим, что оно изображает не просто природу, а природу в ее вечном движении.

В картине Н. Марци звериный стиль отражен в символическом изображении рогов, сбруя коня также является ярким воплощение скифских украшений: здесь это так называемые медные бусы. Образ лошади мифологичен, так как тоже сочетает в себе элементы звериного стиля. Хорошо известно, что когда умирал вождь, его хоронили вместе с драгоценностями, предметами быта и нарядными лошадьми; лошади должны были сопровождать его в загробной жизни. Именно поэтому при жизни у хозяина и лошади налаживалась тесная связь.

Если анализировать композиционный строй картины и ее колорит, то можно отметить, что картина строится на золотистых и охристых оттенках, что символизирует богатство вождя. Художник пользуется приемом лессировки, позволяющим мягко описывать окружающую среду и акцентировать внимание на главном центре композиции. Богатые украшения лошади и расшитая золотой нитью ткань одежды дают основание предположить, что перед нами - вождь одного из скифских племен. Однако автор так мягко написал его, что создается впечатление образа, находящегося между реальностью и потусторонним миром. Сам художник говорит: «Природные условия Горного Алтая, гуляющие в долине ветра, способны менять облик природы». Бурные реки, могучие горы, ущелья и равнины - все это придает природе загадочные, фантастические формы.

Именно такие фантастические мотивы художник придает картине «Дух первого снега» (рис 5). Художник фактически оживляет природу: в Курайской степи падают первые снежинки, пробуждая своим падением древнее недвижимое существо [6]. Лицо древнего старца выражает умиротворение, а закрытые глаза символизируют спокойствия; в этом лице мы можем наблюдать черты, присущие народам Горного Алтая, поэтому оно больше похоже на собирательный образ. Возникает ощущение, что он вот-вот откроет глаза и проснется от легкого дуновения ветра. А пока стоит такая тишина, которая редко возникает в природе: на картине изображен тот эпический момент, когда природа будто бы замерла. Автор нередко словно бы оживляет и персонифицирует природу и наделяет ее человеческими качествами; этот подход красной нитью проходит через многие работы Николая Марци. Его творчество наполнено особыми смыслами и символами, к которым нам удалось лишь слегка прикоснуться.

Колорит картины строится на сочетании контрастных оттенков: теплый передний план наполнен охристыми и розоватыми тонами, что помогает легко воспринимать сюжет. 


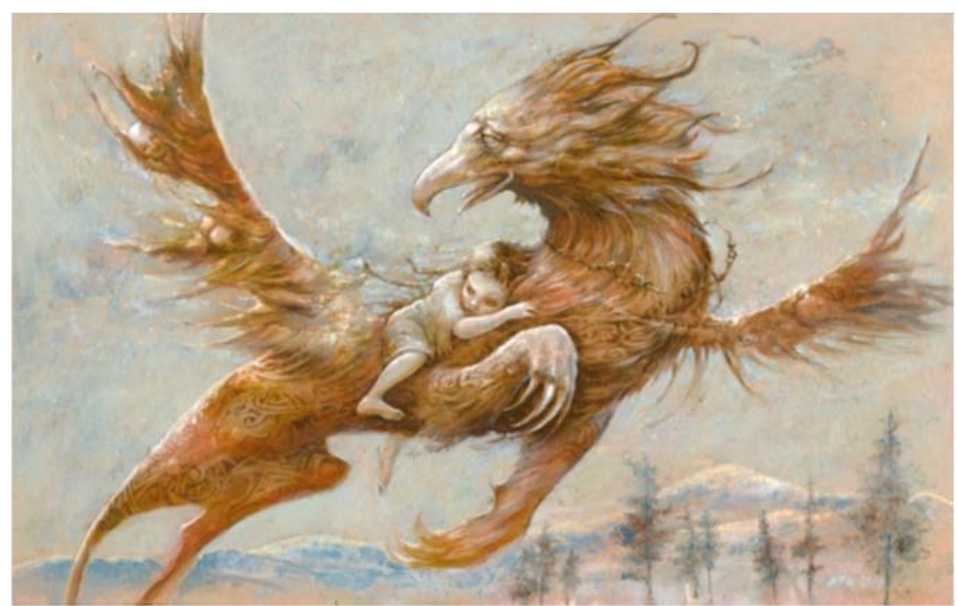

Рис. 3.
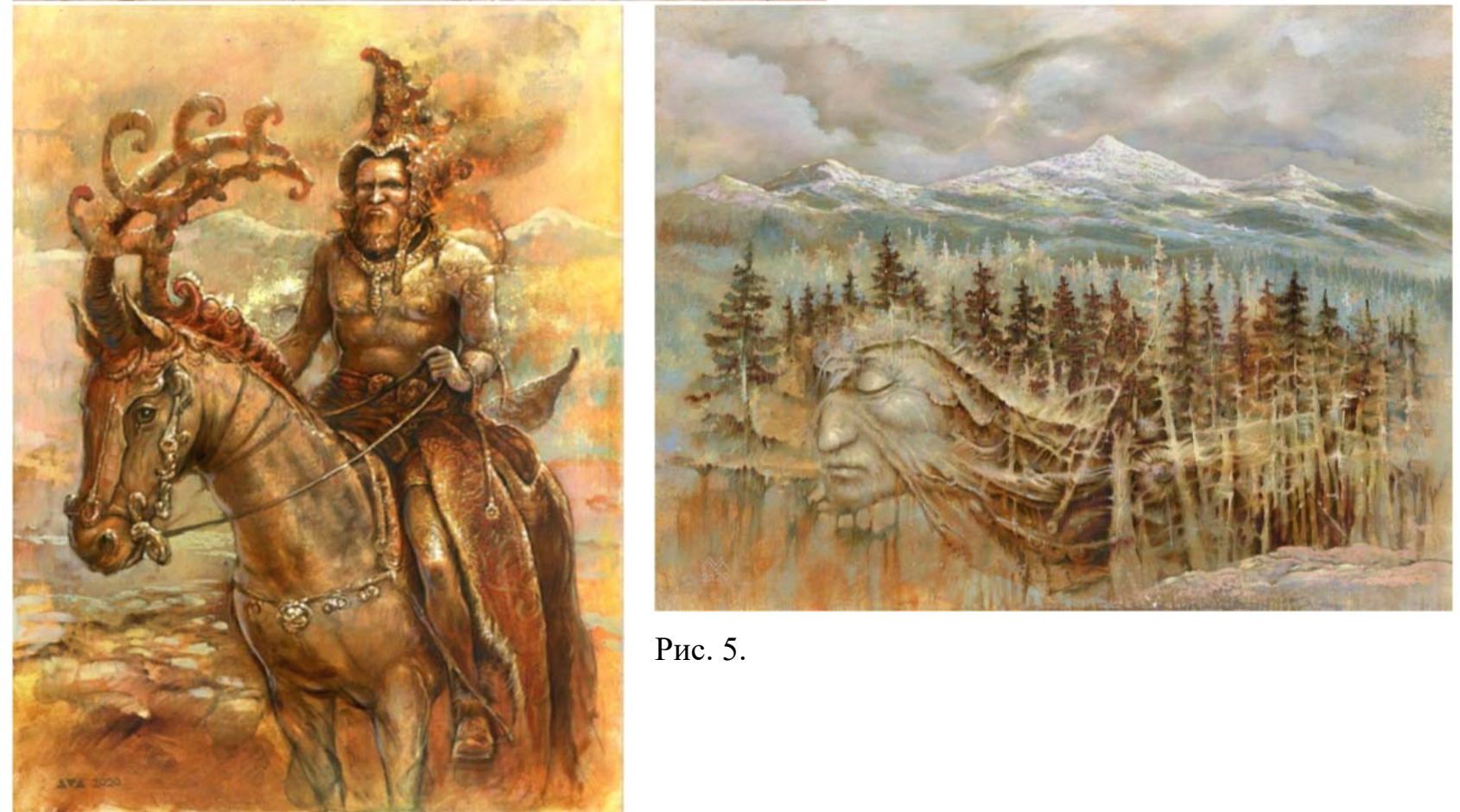

Рис. 5.

Рис. 4.

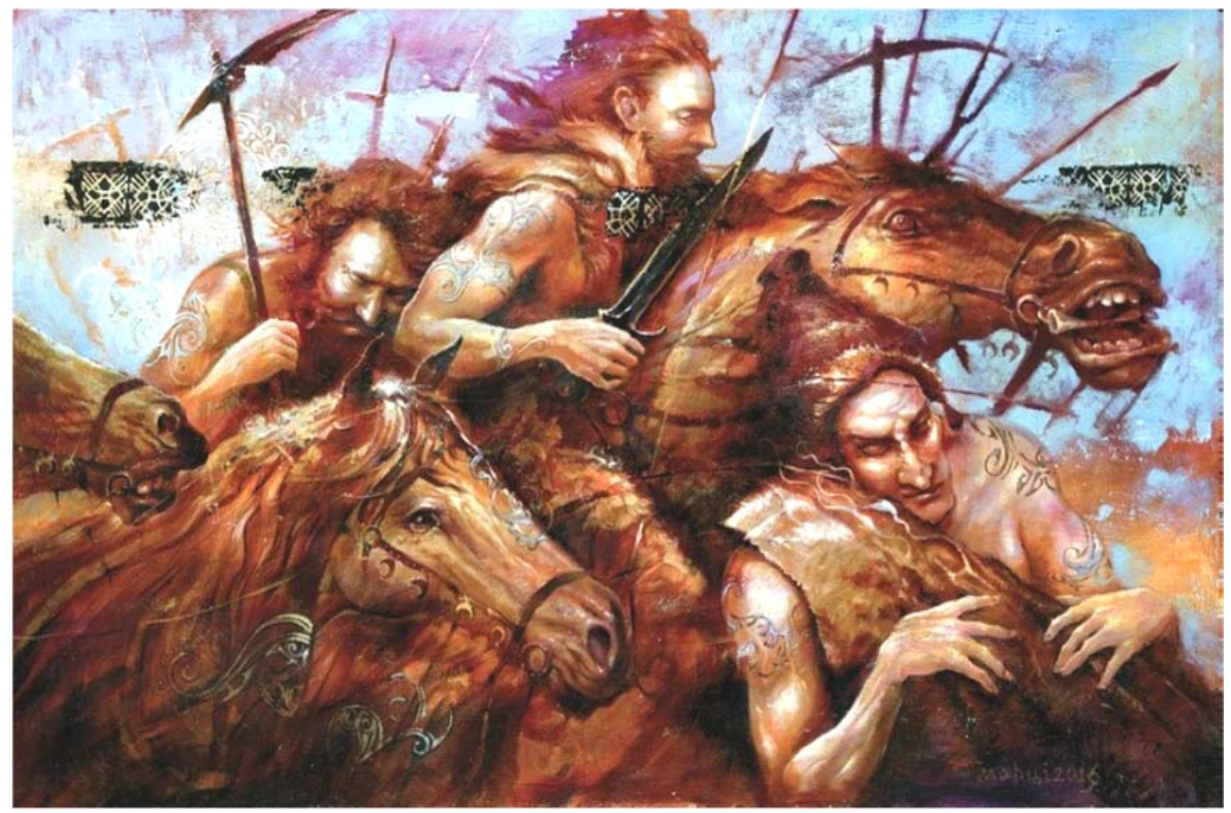

Рис. 6. 
Дальний план окутан холодными жемчужно-фиолетовыми оттенками, что создает ощущение «глубины в картине». Деревья, склонившие свои тяжелые ветви под тяжестью кроны, не смеют шевельнуться и нарушить покой природы: они стоят, прочно укрепив свои корни на самом берегу водоема. С большой высоты эти хвойные деревья могут видеть свое отражение в неколебимой глади горного озера. Сочетание двух миров реального и потустороннего настоящего и отражаемого, гармонично сочетаются в единстве колорита, формы и замысла. Прием пересечения двух миров является одним из излюбленных автором.

Древнегреческий историк и географ Геродот, среди прочего, сообщает очень важную деталь: «Среди всех известных нам народов только скифы обладают одним, но зато самым важным для человеческой жизни искусством. Оно состоит в том, что ни одному врагу, напавшему на их страну, они не дают спастись; и никто не может их настичь, если только сами они не допустят этого. Ведь у скифов нет ни городов, ни укреплений, и свои жилища они возят с собой. Все они конные лучники и промышляют не земледелием, а скотоводством; их жилища - в кибитках. Как же такому народу не быть неодолимым и неприступным? Этой особенности скифов, конечно, благоприятствует их земля и содействуют реки» [7]. Геродот указывает на сильный и непобедимый нрав скифов, эту силу и динамичность пытается передать нам Николай Марци в своей картине «Скифский набег» (рис. 6).

Знаменитая скифская триада, в которую входят конская сбруя и оружие, всегда давала большое преимущество в бою, особенно ближнем. Способность скифского войска совершать марши на огромные расстояния, вести стрелковый бой, пользуясь луком и при этом легко и быстро перемещаться во время сражения, опиралась на наличие конницы.

Приручение лошади позволило человечеству совершить целый ряд рывков в развитии современной цивилизации. В первую очередь это относится к массовым переселениям народов, которые стали менять постоянные места своего проживания, перемещаясь на огромные расстояния. Именно поэтому возникла столь широкая географическая и историческая общность, как скифы, которые, не теряя своей культуры, отстаивая и защищая свои интересы, активно осваивали огромные территории. Безусловно, иногда они встречали сопротивление, однако из-за сурового нрава и силы духа почти всегда выходили из боя победителями.

Картина «Скифский набег» особенно интересна: она изображает полное единение коня и человека. В этом войске почти теряется индивидуальность воинов, потому что они действуют как единый организм, у которого каждый орган отвечает за определенные функции; именно это позволяет ему держать в тонусе систему жизнеобеспечения. Динамичное, цельное пятно соединенных силуэтов с частыми ритмами копий указывает нам на напряженность военных действий, где самым важным качеством для победы является отвага.

Подводя итоги, можно сделать вывод, что картины Николая Марци уникальны по своей сущности: они отражают многие сферы духовной жизни людей - веру в духов, способы общения человека с природой, способность к искусству, создание оригинального звериного стиля. Важно отметить, что его работы создаются на основе изучения археологических коллекций и научных трудов. Они гармонично сочетают в себе мифологическую составляющую наряду с научным знанием. Археологические вещественные источники помогают восстанавливать историческое прошлое; однако они не способны в полной мере отразить духовную сферу жизни древних народов.

Скифы - одна из фундаментальных культур человечества, корни теряются в архаике, и восстановить эти нити очень важно. Николай Марци это делает посредством художественной переработки основных образов древних скифоидных культур, накладывая на них образы места - Горного Алтая. Художник фактически вносит свой вклад в сохранение культурноисторической памяти народа: перерабатывая наследие скифских культур, средствами изобразительного искусства он создает яркие явления современной культуры, наполненные древними смыслами и образами. 


\title{
Список литературы
}

1. Стенографический отчёт о церемонии вручения Государственных премий Российской Федерации, 12 июня 2014 г.// Президент России: [офиц. сайт]. - Москва, 2021. - URL: http://www.kremlin.ru/events/president/transcripts/45898 (дата обращения: 19.05.2021).

2. Коробейникова, Т. С. Археоарт как отличительная черта творчества сибирских художниковавангардистов 60-80-х гг. ХХ в. // Вестник Томского университета. - 2012. - № 361. - С. 51-54.

3. Гумелёв, В. Ю. Скифы азиатские / В. Ю. Гумелёв, Т. М. Юдин, А. А. Постников // Гуманитарные научные исследования. - 2017. - № 2. - URL: https://human.snauka.ru/2017/02/19845 (дата обращения: 19.05.2021).

4. Интервью с [новосибирским художником] Николаем Марци про выставку Скифы Алтая [в выставочном зале Дома Учёных Сибирского отделения Российской академии наук (22 января -10 февраля 2019 г.)]. Академгородок // YouTube, видеохостинг : [сайт]. - Сан-Бруно (Калифорния, CША), - 2021. - URL: https://www.youtube.com/watch?v=w8AB8FDfVmE (дата обращения: 10.05.2021 г.)

5. Октябрь, Д. О выставке [новосибирского художника] Николая Марци «Скифы Сибири. Пробуждение» [в Алтайском государственном краеведческом музее, февраль-март 2021 г.] // YouTube, видеохостинг : [сайт]. - Сан-Бруно (Калифорния, США), - 2021. - URL: https://www.youtube.com/watch?v=y-MAS49LYVY (дата обращения: 10.05.2021).

6. Марци, Н. Картины из серии «Сибирские скифы» // Авторский сайт художника Н. Марци. Новосибирск, 2021. - URL: http://artmarci.ru/art_gallery (дата обращения: 20.05.2021).

7. Геродот. История в девяти книгах / пер. и примеч. Г. А. Стратановского ; под общ. ред. С. Л. Утченко ; ред. пер. Н. А. Мещерский. - Ленинград : Наука. Ленингр. отд-ние, 1972. - 600 с., 1 л. портр.

\author{
Anastasiia A. Sukhareva \\ Altai State Institute of Culture (Barnaul, Russia) \\ aarturovna1999@mail.ru
}

Scientific Chief - Irina V. Kuriianova, Dr. Of Historical Sciences, Associate Professor

Altai State Institute of Culture (Barnaul, Russia)

irinak-63@mail.ru

\section{IMAGES FROM SCYTHIAN MYTHOLOGY IN PAINTER NIKOLAI MARTSI'S ARTWORKS}

\begin{abstract}
The paper analyses problems in preserving cultural and historical memory in the context of diversity of Siberian regional heritage; importance of strengthening cross-cultural relations through the art is stated, the author considers art as a mean for "documenting" cultural and historical memory. The researcher describes creative activity of painter from Novosibirsk (Russia), Nikolay Martsi (born in 1973) who is outlined as a mediator between the modernity and Scythian world of faraway historical past. His paintings can be viewed as a phenomenon of preservation of cultural and historical memory, re-forming images of Scythian epoch, reflecting spiritual life of Altai Mountains' peoples.
\end{abstract}

Keywords: cultural and historical memory, art, archeoart, Scythians, Scythian-Siberian world, Pictures, Nikolai Martsi. 